\title{
OPPOSITION TO THE AMERICAN LEADERSHIP BY BRAZILIAN NURSES (1934-1938)
}

\author{
Tânia Cristina Franco Santos ${ }^{1}$ \\ Gertrudes Teixeira Lopes ${ }^{2}$ \\ Fernando Porto ${ }^{3}$ \\ Aline Silva da Fonte ${ }^{4}$
}

Santos TCF, Lopes GT, Porto F, Fonte AS. Opposition to the american leadership by Brazilian nurses (19341938). Rev Latino-am Enfermagem 2008 janeiro-fevereiro; 16(1):130-5.

A historical social descriptive study whose objective is to describe the circumstances where Bertha Pullen assumes as the din of Anna Nery Nursing School, to assess the strategies undertaken by Pullen to assure her position of power and prestige in the space of the school and Brazilian nursing; and to discuss about the resistance to the presence and authority of the American din, for the nurses and students, in the struggle for a national identity. Corpus analysis was made by putting photographs into context base don written documents and secondary sources. Results: The second management of Pullen was the reiteration of the American presence in the leadership of the School, despite the resistance of the nurses and students. Thus, we may assume that the second tenure of Pullen did not represent a real need that was felt by the school.

DESCRIPTORS: history of nursing; schools, nursing; emblems and insignia

\section{RESISTENCIA AL LIDERAZGO NORTE-AMERICANO EN LA FORMACIÓN DE LA ENFERMERA BRASILEÑA (1934-1938)}

Estudio histórico-social que tuvo como objetivos: describir las circunstancias en las que Bertha Pullen asume la dirección de la Escuela de Enfermería Anna Nery; analizar las estrategias emprendidas por Pullen para asegurar su posición de poder y prestigio en la escuela y en la enfermería brasileña y discutir las oposiciones frente a su presencia y autoridad como directora americana por parte de las enfermeras $y$ alumnas en la lucha por una identidad nacional. El análisis de los documentos fue a través de la contextualización de fotografías, con base en documentos y fuentes secundarios. El estudio demostró que la segunda gestión de Bertha Pullen reiteró la presencia americana dentro del liderazgo de la Escuela de Enfermería de Anna Nery, a pesar de la resistencia de las enfermeras y alumnas. De este modo, se concluye que su segunda gestión en la Escuela de Anna Nery no representó una necesidad real o sentida por la misma escuela.

DESCRIPTORES: historia de la enfermería; escuelas de enfermería; emblemas e insignias

\section{RESISTÊNCIA À LIDERANÇA NORTE-AMERICANA NA FORMAÇÃO DA ENFERMEIRA BRASILEIRA (1934-1938)}

Estudo histórico-social teve como objetivos: descrever as circunstâncias em que Bertha Pullen assume a direção da Escola de Enfermagem Anna Nery; analisar as estratégias empreendidas por Pullen para assegurar sua posição de poder e prestígio no espaço da escola e da enfermagem brasileira e discutir as resistências à presença e autoridade da diretora americana, pelas enfermeiras diplomadas e alunas, na luta pela identidade nacional. A análise do corpus documental se fez a partir da contextualização das fotografias, com base nos documentos escritos e fontes secundárias. O estudo evidenciou que a segunda gestão de Bertha Pullen se configurou como a reiteração da presença americana na liderança da Escola de Enfermagem Anna Nery, apesar da resistência das enfermeiras e alunas. Desse modo, pode-se concluir que a segunda gestão de Bertha Pullen na Escola de Enfermagem Anna Nery não representou necessidade real ou sentida pela própria escola.

DESCRITORES: história da enfermagem; escolas de enfermagem; emblemas e insígnias

${ }^{1}$ Ph.D. in Nursing, Adjunct Professor, Rio de Janeiro Federal University Anna Nery School of Nursing, Brazil, e-mail: taniacristinafsc@terra.com.br; ${ }^{2}$ Free Lecturer, Full Professor, Rio de Janeiro State University School of Nursing, Brazil, e-mail: gertrudeslopes@uol.com.br; ${ }^{3}$ RN Doctoral Student in Nursing, Rio de Janeiro Federal University Anna Nery School of Nursing, Brasil, Assistant Professor, Rio de Janeiro State Federal University Alfredo Pinto School of Nursing, Brasil, e-mail: ramosporto@openlink.com.br; ${ }^{4}$ Undergraduate Nursing Student, Rio de Janeiro Federal University Anna Nery School of Nursing, Brazil, e-mail: alinefonte@globo.com 


\section{INITIAL CONSIDERATIONS}

The introduction of Nightingale nursing model in Brazil, in the beginning of the 20's occurred under the aegis of public health, within a great sanitary reform, led by scientist and sanitarian Carlos Chagas, who was then the director of the National Public Health Department. This reform made it possible for the coming of a group of American nurses, from a mission that was called at the time Missão de Cooperação Técnica para o Desenvolvimento da Enfermagem no Brasil (Mission for Technical Cooperation for the Development of Nursing in Brazil), to meet the needs of the department, considered as necessary to make Carlos Chagas' reform effective. This mission stayed in Brazil for one decade (1921-1931).

The introduction of a new Nursing model in Brazil, under the influence of the Nursing Mission, was concrete after the creation of the Nursing School and a Nursing Service, both ran by American nurses.

With the creation of the Nursing School of the National Department on Public Health, in 1922, the American nurses brought to Brazil a nursing model that added to the traditional features of the Nightingale model, other features developed in their process to adapt to the American culture since the period of the civil war.

The classical model of modern nursing introduced by the Americans determined the selection of unmarried women with good social and education background, and the emphasis on hierarchy and discipline, learning through practice and subordination to medicine mitigated by management autonomy.

As American characteristics, the teaching model introduced here was based on Standard Curriculum and on Goldmark Report that advocated autonomy in relation to the hospital. In the case of Brazil, Nursing autonomy at Hospital São Francisco de Assis (main place of practice for students) was assured by the simultaneous performance of the role of principal of the Escola de Enfermeiras do Departamento Nacional de Saúde Pública (Nursing School of the National Department of Public Health) and of chief at the Serviço de Enfermagem (Nursing Service) in this hospital by one person.

The Escola de Enfermeiras do Departamento Nacional de Saúde Pública, currently named Anna Nery Nursing School began its activities on February $19^{\text {th }} 1923$, and the principal was the American nurse
Claire Louise Kieninger (1923-1925). From 1925 to1928 the school was ran by Loraine Geneviéve Dennhardt.

It is worth mentioning that both tenures by Bertha Pullen in the school Office were due to special circumstances. Her first tenure, as the third principal at Anna Nery Nursing School (1928-1931), was a period of extension of the mission of the American nurses in Brazil, due to a government decision, since the initial agreement set its end in 1928.

When the mission finished in 1931, the board at Anna Nery Nursing School puts Rachel Haddock Lobo, a Brazilian nurse, in charge. However, her early and unexpected death in 1933 puts once again powerful interests at stake, regarding the choice of a new principal for the school. Although the National Department on Public Health already had 125 students graduated at Anna Nery Nursing School, and 17 had post graduation in the United States, the final decision was that Bertha Pullen came back to Brazil to be in charge of the school in a second tenure (1934-1938).

The present study aims at reinforcing the American leadership in the education of Brazilian nurses, through the second tenure of Bertha Pullen (1934-1938) as the principal at Anna Nery Nursing School. To deal with the issue presented, the following objectives have been designed: describe the circumstances in which Bertha Pullen takes on the management of Anna Nery Nursing School; to assess the strategies used by her to ensure her position of power and prestige in the school and in Brazilian Nursing, and to discuss the resistance to her presence and authority by graduated nurses and students struggling for a national identity.

\section{METHODS}

The present study, performed through the social history perspective called "Emblemas e rituais na formação da identidade da enfermeira brasileira" (Symbols and rituals in the formation of the Brazilian Nursing Identity), has been approved by the Ethical Research Committee at Anna Nery Nursing School / Hospital Escola São Francisco de Assis. Data were assessed at the light of Pierre Bourdieu's theory of the social world, when he studies the setting of the different social spaces, the hierarchies and the interior struggles of these spaces, assessing dialectic relationships among the agents in these $\operatorname{spaces}^{(1)}$. 
The space studied is that of Anna Nery Nursing School, seen in this study as a social space where agents (nurses, professors and students) achieve their position in the division of work that enable them to legitimately manipulate certain symbolic products such as cultural assets $^{(2)}$.

Primary sources were located at the Document Center of Anna Nery Nursing School in the Federal University of Rio de Janeiro, they are photographs and written documents, such as reports, letters, minutes, conference texts, and speeches, both related to the issue and according to the period of time studied. Secondary sources were about the History of Brazil and of Nursing, located in articles, dissertations and theses.

After documents had been selected, external and internal critics were performed to validate the findings of the study, since the critics to sources helped to determine historical evidences that supported the assessment of findings ${ }^{(3)}$.

Corpus analysis was conducted as of contextualization of photographs, based on written documents and secondary sources, allowing linking what was expressed in photographs with the external information. These aspects determine content structure and provided subsidies to assess the object in study ${ }^{(4)}$.

\section{RESULTS}

The return of American leadership expressed by Bertha Pullen managing Anna Nery Nursing School: strategies to fix space

Bertha Pullen takes in the management of Anna Nery Nursing School, on a second tenure on April $2^{\text {nd }} 1934$, and chose as her assistant the Brazilian nurse Maria de Castro Pamphiro, graduated by the first class and with post graduation in the United States. It is worth mentioning that after Rachel Haddock Lobo's death, Maria de Castro Pamphiro ran the School as a deputy principal for seven months.

Bertha Pullen, on her first monthly report on activities, in the end of April 1934, recorded that she was taking over the management of Anna Nery Nursing School again, after being away for precisely two years and nine months. This statement indicates the understanding of the principal that the management of Rachel Haddock Lobo, interrupted by her death, was only a short break in the American leadership in the management of school and, at the same time, she mentioned the services she had done in her first management.

Bertha Pullen also made a brief diagnosis of the school situation, saying that it was in poor conditions, however, highlighting that the general organization principles have remained the same. She pointed out the need for reviewing the theoretical contents and the practical experiences.

To keep her authority and control of professors and students, the principal tried to establish direct communication with students, adopting the strategy of holding informal events where professors would attend. Thus, in the second month of her tenure, the "Social Hour" was established every Mondays at the principal's office.

This situation, although apparently made the principal and the students closer, reinforced the social distance, since social reality is characterized by situations that reflect having a set of features given to the socially valued and at the same time make people realize their limits, when they internalize external determinations, in the sense that they either admit or accept what was given to them, according to their habitus.

Regarding the professors, a mandatory course was introduced "Teaching of Nursing and Infirmary Management". The first classes dealt with "studying building of character: how to study and rebuild it". This determination shows the concern with standardizing behavior of students and professors, through strategies that aim at producing agents [nurses] with a secondary habitus that is, of a secondary ethos, as a result of internalizing the structures of this field, since the education system, as a reproductive instance "when it performs its inculcation task, makes the culture that it has to reproduce worth of being preserved" ${ }^{\prime(5)}$.

In other words, the strategy of the principal of offering a mandatory course for professors, made it possible to update the professional habitus, to adjust it to the new demands, since the habitus while it was modus operandi and primary condition for any purpose, demands, from the groups and/or agent classes, a minimal control and domain of a common code, even if it is an unaware record ${ }^{(5)}$, since the habitus as it is incorporated and introduced by family education, is constantly updated over the social path, tracing the limits of agents. 
The rituals and symbols of the profession, introduced since the inauguration of the course at Anna Nery Nursing School, in 1923, by American nurses as "symbols of the social reality"(5) had, above all, the role of introducing and legitimating a new symbolic order, since these rituals gave visibility to this new profession that was eager for social recognition. Additionally, the symbolic efficiency of rituals is in the possibility of stating the identity of a profession.

Bertha Pullen, on her second tenure as principal, continued with the "Capping ceremony" which represented the effective integration of students to the student body of the school, symbolizing Nursing as a universal value and at the same time using a strategy of making the group equal and different, giving duties and advantages, in the symbolic level, to those who wore it, and who belonged to that group $^{(4)}$, because rituals are a set of formal, expressive acts, with a symbolic dimension that uses as a resource specific language and behavior systems, as well as symbolic objects with meaning representing a symbolic asset of the group $^{(6)}$.

Figure 1 shows Bertha Pullen, helped by Zaíra Cintra Vidal, puts the coif in the head of one of the students, while the student lights her candle on the flame of the previous student's candle. Lighting candles in the ritual gives it one more symbolic meaning since "primary symbolism of candles is that of faith in ones truth and beauty that goes beyond existence in itself, determined by enduring commitment to a service" ${ }^{\prime(4)}$.

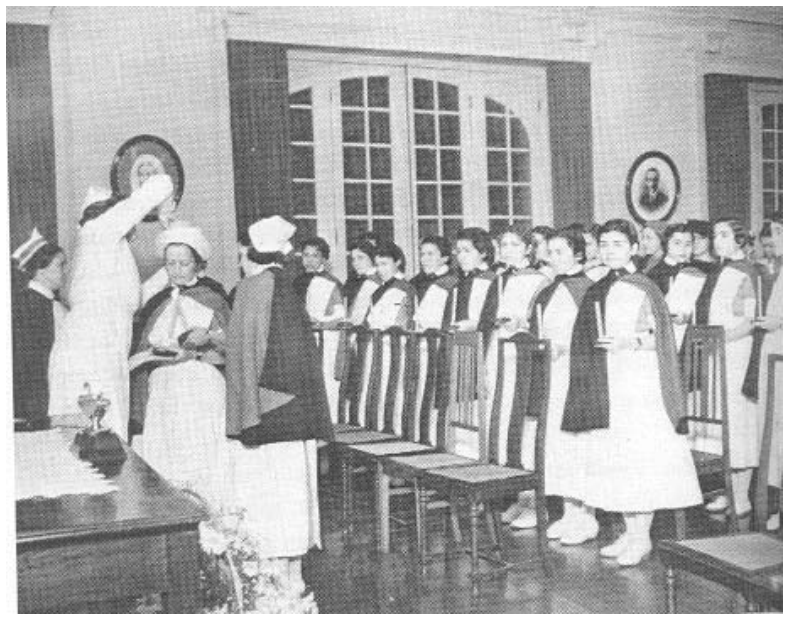

Figure 1 - Capping ceremony

The place is the Main room of the students' dorm, and the year is 1936. On the table there is a bulb, icon of the world's Nursing bringing back the memory of Florence Nightingale.
Receiving the coif in front of the bulb and passing on the flames to all candles by all students reinforces the commitment with the future profession. Understanding the importance of these symbols can be seen in this extract of a text produced by a student at Anna Nery Nursing School called "A Lâmpada simbolo de nossa Fé" ("The Bulb, a symbol of our faith"), published at Revista Anaes de Enfermagem (A Nursing Journal), currently the Brazilian Nursing Journal, in September 1937, she states: "Let us show to be worth of such advantages and benefits, that is, let us perform our duty. Only this way may we see the bulb that is our symbol shining on the universal light".

The rituals of receiving the degree at Anna Nery Nursing School were always a time and space important for all principals of the school who called people from different sectors of society making the group important for them and for the others. Institutional rituals produced by the school had the effect of making the group legitimate, because the symbolic efficiency of rituals depend on the power of the authorities introducing them and the provisions of the receivers to know and acknowledge the institutional conditions for a valid ritual ${ }^{(7)}$.

Thus, the ritual of receiving the degree reassured the commitment of students with their profession, since the symbolic efficiency of rituals lie in changing the representation that agents have on the legitimate person, changing the nature of social relations and at the same time, transforming the representation that people have of themselves, as well as behaviors that are considered essential to be adopted in order to adjust to this representation ${ }^{(7)}$.

Thus, rituals have the effect as the symbolic record, because they do not show the passage from one state to another, but they determine incorporation of a professional habitus in accordance with the social expectations connected with its category.

Realigning positions of power and prestige: resistance to foreign leadership in Brazilian Nursing

The inauguration of Rachel Haddock Lobo's portrait, due to the first anniversary of her death, on September 26th 1934, first year of Bertha Pullen's tenure as principal at Anna Nery Nursing School shows some demonstrations of resistance to Bertha Pullen's leadership, according to the placement of people in the geographic space, represented on Figure 2 which 
refers to the inauguration of the Portrait of Rachel Haddock Lobo, in the Main Room of the Students' Dorm.

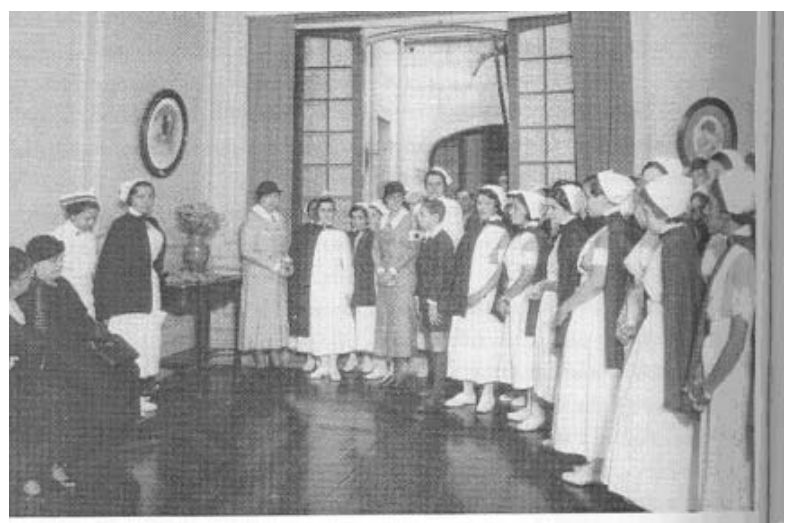

Figure 2 - Ritual to Inaugurate Rachel Haddock Lobo's portrait

The portrait of Rachel Haddock Lobo: on the left is the then Superintendent of the Service of Nurses of the National Department on Public Health, Edith de Magalhães Fraenkel, standing, with a public health nurse uniform and by student Anita Guanais Dourado, speaker of the students' group; on the right nurse and professor Zaíra Cintra Vidal. The two seated ladies, wearing dark clothes and looking prostrated, next to Zaíra Cintra Vidal are Rachel Haddock Lobo's relatives.

The two men on the photograph outside the room have not been identified; but the written documents led to infer that they are relatives from Rachel Haddock Lobo, since the documents make a reference to Sydney Haddock Lobo, Rachel's brother, and he even read a speech paying tribute to her. There are also about 10 students in uniform in the picture.

Regarding identification of the other people on the photo, next to Edith de Magalhães Fraenkel, we can see nurse Maria de Castro Pamphiro, that was then the principal assistant (this position corresponds to deputy principal nowadays), on a nurse hospital uniform.

The school principal, Bertha Pullen, also wearing a hospital nurse uniform, is right behind the profile of the only boy on the photo (Rachel Haddock Lobo's nephew). Her position on the photo, far from Rachel's portrait and from the Brazilian managers, puts her on a prominent position just because of her height.

This data becomes more expressive when put together with the fact that she did not speak during the event, therefore, she was not acknowledged by nurses and students as an authorized spokesperson, since the "spokesperson is that who is supposed to talk on behalf of the community; it is at the same time their privilege or duty, their role; that is, their competence $^{\prime(7)}$.

Not withstanding, the positioning of the principal can be explained at the light of what Bourdieu called "strategy of condescension", since Bertha Pullen, when she positioned herself away from Rachel Haddock Lobo's portrait and did not speak, she makes evident the case of symbolic transgressions, where the "legitimate condescending people, have the privilege of all privileges, and take advantage of them ${ }^{\prime \prime}(7)$, therefore, transgressions that are prohibited to other agents are authorized, expressing that she is aware of her cultural capital and professional identity.

However, the spatial distribution of Brazilian nurses in the ceremony reflects the struggle for imposing the view of the world "in glasses that enable people to see the world according to certain divisions" ${ }^{(8)}$ which defines hierarchical positions of the field, in the specific case, Anna Nery Nursing School, when Brazilian nurses placed themselves next to Rachel's portrait (a special place in the ceremony), at the same time it gave visibility to the leadership of the Brazilian nurse in the direction of the school that was considered the standard at the time, it also made clear the resistance to the foreign leadership.

These strategies that reflect the fight for legitimate monopoly of power of Brazilian nurses through the use of collective capital of "prestigious" nurses, determined by their "position in the objective structure of the authority relations, that is, of authority and force that they have achieved during their fight"(5).

\section{FINAL CONSIDERATIONS}

Both tenures from Bertha Pullen (1928-1931) and (1934-1938), separated by the brief management of the Brazilian nurse, Rachel Haddock Lobo, are the reiteration of the American presence running Anna Nery Nursing School, despite resistance of graduated people and students.

The concern of the principal in keeping rituals started due to the inauguration of Anna Nery Nursing School is justified by the possibility of legitimating a nursing model for the Brazilian society, since 
institutional rituals have the role of attributing and distinguishing new qualities, giving to groups mean to work on the social reality.

Despite the strategies of the principal to control the group, the second management is a period of resistance to the presence and authority because what was at stake was the building of a new national and native identity. Thus, we may conclude that the second management of Bertha Pullen at Anna Nery
Nursing School was not a real representation or a representation sensed by the school.

To conclude with, it is worth mentioning that although the reiteration of the American presence has corresponded to an enforcement of a world view considered legitimate, on the other hand, helped Brazilian nurses update their habitus through professional relations with Bertha Pullen, through the incorporation of social and cultural capital ${ }^{(9)}$.

\section{REFERENCES}

1. Boudieu P. O Poder Simbólico. Rio de Janeiro (RJ): Bertrand do Brasil; 1989.

2. Pinto L. Pierre Bourdieu e a Teoria do Mundo Social. Rio de Janeiro (RJ): FGV; 2000.

3. Padilha MICS, Borenstein MS. O método de pesquisa histórica na enfermagem. Texto E Contexto Enfermagem 2005 outubro; 14(4):575-84.

4. Santos TCF, Barreira IE. O poder simbólico da enfermagem norte-americana no ensino da enfermagem na capital do Brasil (1928-1938). Rio de Janeiro (RJ): Ana Nery; 2002.

5. Bourdieu P. A economia das trocas simbólicas. São Paulo (SP): Editora Perspectiva; 2001.

6. Segalen M. Ritos e Rituais Contemporâneos. Rio de Janeiro (RJ): FGV; 2002.

7. Bourdieu P. A economia das trocas lingüísticas $O$ que falar quer dizer. 2 ed. São Paulo (SP): Edusp; 1998.

8. Bourdieu P. Sobre a Televisão. Rio de Janeiro (RJ): Jorge Zahar Editor; 1997.

9. Bernardes MMR, Lopes GT, Santos TCF. O cotidiano das enfermeiras do Exército na Força Expedicionária Brasileira (FEB) no Teatro de Operações da $2^{a}$ Guerra Mundial, na Itália (1941-1945). Rev Latino-am Enfermagem 2005 maio-junho; $13(3): 314-21$ 